\title{
Selective Hydrogenation of 1,3-Butadiene by Transition Metal Compounds Immobilized in 1- Butyl-3-methyl Imidazolium Room Temperature Ionic Liquids
}

\author{
Crestina S. Consorti ${ }^{a}$, Alexandre P. Umpierre ${ }^{a}$, Roberto F. de Souza ${ }^{a}$, Jairton Dupont ${ }^{a}$ and \\ Paulo A. Z. Suarez, ${ }^{*, b}$ \\ ${ }^{a}$ Instituto de Química, Universidade Federal do Rio Grande do Sul, Av. Bento Gonçalves, 9500, \\ 91501-970 Porto Alegre - RS, Brazil \\ ${ }^{b}$ Instituto de Química, Universidade de Brasília, CP 4478, 70919-970 Brasília - DF, Brazil
}

\begin{abstract}
Os complexos $\left[\mathrm{Co}(\mathrm{acac})_{2}\right],\left[\mathrm{Co}(\mathrm{acac})_{3}\right],\left[\mathrm{Fe}(\mathrm{acac})_{3}\right]$ e $\left[\mathrm{Ni}(\mathrm{acac})_{2}\right](\mathrm{acac}=$ acetilacetonato $)$ dissolvidos em tetrafluoroborato de 1-butil-3-metilimidazônio (1), trifluorometanosulfonato de 1butil-3-metilimidazólio (2) ou hexafluorofosfato de 1-butil-3-metilimidazólio (3), catalisam a hidrogenação de 1,3-butadieno em butenos em sistema catalítico tipicamente bifásico. A conversão do 1,3-butadieno, a seletividade e a frequiência de rotação (TOF) são fortemente dependentes do metal de transição e do líquido iônico. Para $\left[\mathrm{Co}(\mathrm{acac})_{2}\right]$ dissolvido em 1, estudos cinéticos sugerem que a reação ocorre no meio líquido iônico, com uma energia aparente de ativação de of $33.8 \mathrm{~kJ} \mathrm{~mol}^{-1}$. A solução iônica do catalisador pode ser recuperada e reutilizada várias vezes sem mudanças perceptíveis na atividade e seletividade da reação.
\end{abstract}

The compounds $\left[\mathrm{Co}(\mathrm{acac})_{2}\right],\left[\mathrm{Co}(\mathrm{acac})_{3}\right],\left[\mathrm{Fe}(\mathrm{acac})_{3}\right]$ and $\left[\mathrm{Ni}(\mathrm{acac})_{2}\right](\mathrm{acac}=$ acetylacetonate $)$ dissolved in 1-butyl-3-methyl imidazolium tetrafluoroborate (1), trifluoromethanesulphonate (2) or hexafluorophosphate (3) catalyze the reduction of 1,3-butadiene into butenes in a typical two-phase catalytic reaction. The 1,3-butadiene conversion, the selectivity and turnover frequencies (TOF) are strongly dependent on the nature of the transition metal catalyst precursor and the ionic liquid. For $\left[\mathrm{Co}(\mathrm{acac})_{2}\right]$ dissolved in $\mathbf{1}$, kinetic studies strongly suggest that the reaction takes place in the ionic solution bulk, having an apparent activation energy for the overall process of $33.8 \mathrm{~kJ} \mathrm{~mol}^{-1}$. The recovered ionic catalyst solution can be reused several times without any significant changes on activity and selectivity.

Keywords: biphasic hydrogenation, ionic liquids, dienes, cobalt catalysts

\section{Introduction}

The hydrogenation of dienes to mono-olefins has several potentially useful applications in industry. In applications where only moderate selectivity is required heterogeneous catalysts excel due to their easy separability from reaction products by decantation or filtration, and the catalyst can be recycled. ${ }^{1-5}$ Transition metal catalyst precursors are known to hydrogenate dienes to olefins under homogeneous conditions. ${ }^{1,2}$ In these cases, however, $\mathrm{C}=\mathrm{C}$ bond isomerization reactions are also operative decreasing the selectivity to hydrogenation products. ${ }^{6}$ Moreover, the separation of the products from the reaction mixture and recovery of the catalyst represent

\footnotetext{
*e-mail:psuarez@unb.br
}

disadvantages of these homogeneous catalytic reactions. ${ }^{3-5}$ The catalytic system formed by dissolving cobalt cyanide in water is highly specific and active (compared with the homogeneous systems) for the hydrogenation of conjugated dienes. ${ }^{7}$ Given the restriction that the cobalt catalyst is rapidly deactivated, this aqueous system remains the best catalyst for the hydrogenation of dienes as far as selectivity is concerned.

Room temperature molten salts (or ionic liquids) have been demonstrated to be the immobilizing agents of choice for various organometallic catalyst precursors. ${ }^{8}$ In these reactions, the catalysts maintain their molecular properties and achieve catalytic activities and selectivities similar to those obtained from the same catalyst precursors in homogeneous media. Indeed, oligomerization, ${ }^{9-12}$ hydroformylation, ${ }^{13}$ hydrogenation ${ }^{13-16}$ and telomerization $^{17}$ reactions have been performed with transition 
metal complexes dissolved in molten salts based on the 1butyl-3-methyl imidazolium cation in typical liquid-liquid two-phase catalytic reactions. We have shown that cobalt cyanide dissolved in 1-n-butyl-3-methyl imidazolium tetrafluoroborate ionic liquid is able to hydrogenate 1,3butadiene into butenes with $100 \%$ conversion and selectivity at room temperature and 25 atm of hydrogen. ${ }^{15}$ However, this catalytic system has been shown to be completely inactive after the catalytic reaction and, therefore, rending impracticable its reuse.

We have also recently communicated that $\left[\mathrm{Pd}(\mathrm{acac})_{2}\right]$ immobilized in $\mathrm{BMI}_{\mathrm{BF}}$ is able to catalyze the selective reduction of simple and functionalized dienes to monoenes under mild conditions in a typically biphasic catalysis. ${ }^{18}$ This reaction can be carried out without any organic solvents and, at the end, the ionic catalyst solution, separated by simple decantation, is suitable for reuse at least fifteen times with no losses in its catalytic behavior. In this work, we wish to report that other acetylacetonate transition-metal complexes, like $\left[\mathrm{Co}(\mathrm{acac})_{2}\right],\left[\mathrm{Co}(\mathrm{acac})_{3}\right],\left[\mathrm{Fe}(\mathrm{acac})_{2}\right]$ and [Ni(acac) $)_{2}$, immobilized in 1-butyl-3-methyl imidazolium based molten salts are able to hydrogenate 1,3-butadiene into butenes in typical two-phase catalytic reactions under mild reaction conditions. Moreover, we present here kinetic and thermodynamic studies which evidence that, for the first time in this area, the reaction occurs preferentially in the ionic liquid catalyst solution.

\section{Experimental}

\section{General}

All manipulations were performed under dry, oxygenfree argon using standard techniques. Mass spectra were obtained with a GC-MS HP5988A (EI, 70 eV). The metal contents in both ionic and organic phases were determined by atomic absorption analysis using a Perkin Elmer 2380, HGA 400, atomic absorption spectrometer with graphite tube atomizer. The reaction products were analyzed by gas chromatography on a Varian $3400 \mathrm{CX}$ chromatograph equipped with an LM100 column (20 m x $0.25 \mathrm{~mm} x$ $0.2 \mu \mathrm{m})$, FID detector; $\mathrm{N}_{2}$ was the carrier $\left(1 \mathrm{~mL} \mathrm{~min}^{-1}\right)$; the temperature program was from $35^{\circ} \mathrm{C}(5 \mathrm{~min})$ to $90{ }^{\circ} \mathrm{C}$ (15 min) at a heating rate of $10^{\circ} \mathrm{C} \mathrm{min}^{-1}$. The 1,3 -butadiene conversion and butenes selectivity were determined by gas chromatography using cyclohexane as internal standard. The catalytic reactions were performed in a $100 \mathrm{~mL}$ stainless steel autoclave, containing a magnetic bar, temperature indicator and a manometer. The consumption of hydrogen was monitored by the decrease of the reactor's pressure.

\section{Materials}

$\left[\mathrm{Co}(\mathrm{acac})_{2}\right],{ }^{19}\left[\mathrm{Co}(\mathrm{acac})_{3}\right],{ }^{20}\left[\mathrm{Fe}(\mathrm{acac})_{3}\right],{ }^{21}\left[\mathrm{Ni}(\mathrm{acac})_{2}\right],{ }^{22}$ and the ionic liquids ${ }^{14}$ were prepared according to literature procedures. 1,3-butadiene was distilled under argon and stored over molecular sieves ( $3 \AA$ ) . All other reagents were obtained from commercial sources and were used as received.

\section{Typical procedure for the hydrogenation reaction}

The ionic liquid $(3 \mathrm{~mL})$ and the transition metal catalyst precursor were mixed in a Schlenk tube and then transferred into the autoclave under argon. Liquid 1,3Butadiene $(10 \mathrm{~mL})$ was introduced and the reactor was pressurized with hydrogen at the desired temperature. The consumption of hydrogen was monitored by the decrease of the reactor's pressure. For the reaction, a well-stirred system is required, since the mass transfer between the phases is an important parameter in these systems (in absence of stirring the consumption of hydrogen is completely stopped). In the kinetic study, the reaction was stopped when previous fixed hydrogen consumption was verified, it means, a comparable conversions were achieved (iso-conversion conditions). For others experiments, the reaction was stopped at the desired time. The conversions and selectivities for all reactions were determined analyzing the organic phase by gas chromatography. After the reaction, the manipulations and separations of the phases were performed under air at $-20^{\circ} \mathrm{C}$. When the ionic phase was reused, this procedure was carried out under argon. The reactions were repeated at least twice in order to ensure reproducibility of the system.

\section{Results and Discussion}

The ionic liquids $\mathbf{1}, \mathbf{2}$ and $\mathbf{3}$ (Scheme 1) containing different non-coordinating anions have been chosen for this study due to their distinct physical-chemical properties. $^{23}$

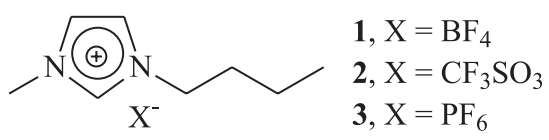

Scheme 1.

The catalyst ionic solution was prepared by simple dissolution of the transition metal complexes into the ionic liquid at room temperature. The results obtained with $\left[\mathrm{Co}(\mathrm{acac})_{2}\right]$ dissolved in $\mathbf{1}$ are summarized in Table 1 . It is worthwhile to mention that the products are easily removed 
Table 1. Conversion (Conv.), selectivity and turnover frequency (TOF) of the hydrogenation of 1,3-butadiene by [Co(acac) ${ }_{2}$ dissolved in $3 \mathrm{~mL}$ of $\mathbf{1}$ at different reaction conditions

\begin{tabular}{|c|c|c|c|c|c|c|c|c|c|}
\hline \multirow[t]{2}{*}{ Entry } & \multirow{2}{*}{$\begin{array}{c}{\left[\mathrm{Co}(\mathrm{acac})_{2}\right]} \\
(\mathrm{mmol})\end{array}$} & \multirow{2}{*}{$\begin{array}{c}\mathrm{P} \\
(\mathrm{atm})\end{array}$} & \multirow{2}{*}{$\begin{array}{c}\mathrm{T} \\
\left({ }^{\circ} \mathrm{C}\right)\end{array}$} & \multirow{2}{*}{$\begin{array}{l}\text { time } \\
\text { (h) }\end{array}$} & \multirow{2}{*}{$\begin{array}{l}\text { Conv. } \\
(\%)\end{array}$} & \multicolumn{3}{|c|}{ Selectivity (\%) } & \multirow{2}{*}{$\begin{array}{l}\text { TOF } \\
\left(\mathrm{h}^{-1}\right)\end{array}$} \\
\hline & & & & & & but-1-ene & but-2-ene & butane & \\
\hline 1 & 0.06 & 25 & 50 & 145 & 64 & 55 & 40 & 5 & 9.3 \\
\hline 2 & 0.10 & 25 & 50 & 123 & 65 & 56 & 40 & 4 & 6.6 \\
\hline 3 & 0.50 & 25 & 50 & 100 & 64 & 56 & 40 & 4 & 1.6 \\
\hline 4 & 1.00 & 25 & 50 & 96 & 67 & 57 & 38 & 5 & 0.9 \\
\hline 5 & 1.50 & 25 & 50 & 96 & 66 & 49 & 42 & 9 & 0.6 \\
\hline 6 & 1.00 & 25 & 25 & 240 & 62 & 57 & 38 & 5 & 0.3 \\
\hline 7 & 1.00 & 25 & 40 & 120 & 70 & 57 & 39 & 4 & 0.7 \\
\hline 8 & 1.00 & 25 & 60 & 70 & 70 & 56 & 40 & 4 & 1.3 \\
\hline 9 & 1.00 & 25 & 70 & 45 & 69 & 56 & 38 & 7 & 1.9 \\
\hline 10 & 0.1 & 15 & 50 & 22 & 22 & 56 & 39 & 5 & 12.6 \\
\hline 11 & 0.1 & 25 & 50 & 22 & 20 & 50 & 43 & 7 & 11.4 \\
\hline 12 & 0.1 & 45 & 50 & 22 & 37 & 52 & 36 & 12 & 21.2 \\
\hline
\end{tabular}

from the reaction mixture by simple decantation and that the recovered ionic catalyst solution can be reused several times (at least seven recycles) without any significant changes in catalytic activity and selectivity. Atomic absorption analysis of the two phases (ionic and organic) after the catalytic reaction indicated that more then $98 \%$ of metal remains into the ionic liquid.

It is evident from the data of Table 1 that the catalytic activity and selectivity on butenes is not influenced by the concentration of the catalyst (entries 1 to 5) working under iso-conversion conditions. This behaviour remains constant for concentrations up to $1 \mathrm{mmol}$ of catalyst / 3 $\mathrm{mL}$ of $\mathbf{1}$ when a sensible decrease in the selectivity was observed (using $1.50 \mathrm{mmol}$ of $\mathbf{1}$ the selectivity on but-1ene decreases from $56 \%$ to $49 \%$ ).

The selectivity to butenes remains almost constant whereas the catalytic activity increases with increasing reaction temperature (entries 6 to 10) under iso-conversion conditions. The conversion and catalytic activity are almost doubled by increasing the hydrogen pressure from 15 to $45 \mathrm{~atm}$ (entries 10 to 12 ).

The kinetics and thermodynamics of the 1,3-butadiene hydrogenation by $\left[\mathrm{Co}(\mathrm{acac})_{2}\right]$ immobilized in $\mathbf{1}$ was investigated by monitoring the reaction at different hydrogen pressures, different temperatures and catalyst precursor concentrations under iso-conversion conditions (see Table 1). The reaction rate $(r)$ shows a direct dependence on the cobalt concentration. The $r$ were calculated from the TOF data (Table 1) and expressed in mol L-1 $\mathrm{s}^{-1}$. Plots of $\log r v s$. $\log [\mathrm{Co}]$ (Figure 1) and $v s$. hydrogen pressure (Figure 2) give straight lines with slopes 0.15 and 0.5 , respectively. Since the 1,3-butadiene concentration was kept constant for all the experiments, the rate law can be written by equation 1 :
$\frac{\mathrm{d}\left[\mathrm{C}_{4} \mathrm{H}_{6}\right]}{\mathrm{dt}}=\mathrm{k}^{\prime} \cdot[\mathrm{Co}]^{0.15} \cdot\left(\mathrm{P}_{\mathrm{H}_{2}}\right)^{0.5}$

where $\mathrm{k}^{\prime}$ is an apparent rate constant which includes Henry's constant and the 1,3-butadiene concentration. Although it is difficult to determine in which phase the reaction occurs, we can assume that the $\mathrm{H}_{2}$ concentration is proportional to the systems pressure, obeying Henry's law. Similar considerations might hold for the 1,3butadiene concentration.

We noticed that dissolving the light orange catalyst precursor $\left[\mathrm{Co}(\mathrm{acac})_{2}\right] \cdot 2 \mathrm{H}_{2} \mathrm{O}$ in the ionic liquids $\mathbf{1}$ and $\mathbf{2}$, a light violet solution is formed. This is a strong indication that the monomeric $\left[\mathrm{Co}(\mathrm{acac})_{2}\right]$ is transformed into an oligomeric structure. Indeed, spectroscopic studies of the ionic solution in the UV region showed a spectrum similar to those described in literature for $\left[\mathrm{Co}(\mathrm{acac})_{2}\right]$ olygomers. ${ }^{23}$

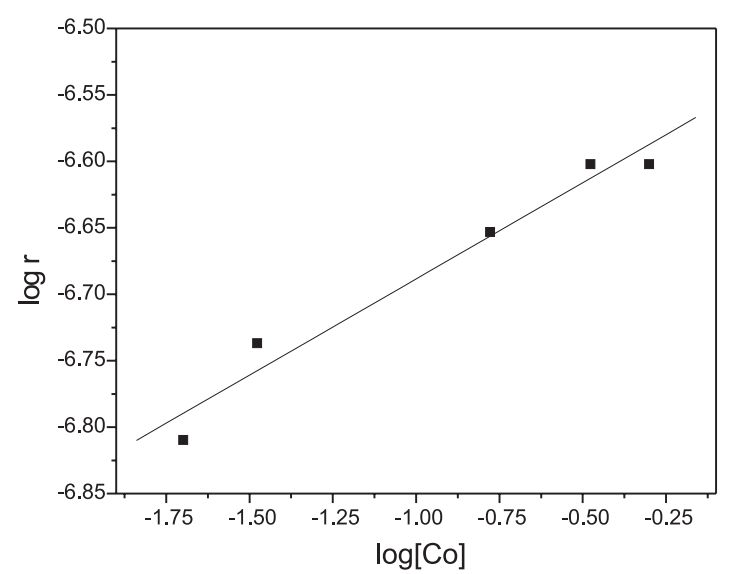

Figure 1. Hydrogenation of $\mathrm{C}_{4} \mathrm{H}_{6}$ to $\mathrm{C}_{4} \mathrm{H}_{8}$ by $\left[\mathrm{Co}(\mathrm{acac})_{2}\right]$ dissolved in 1: rate dependence on catalyst precursor concentration. Conditions are as in Table 1. 


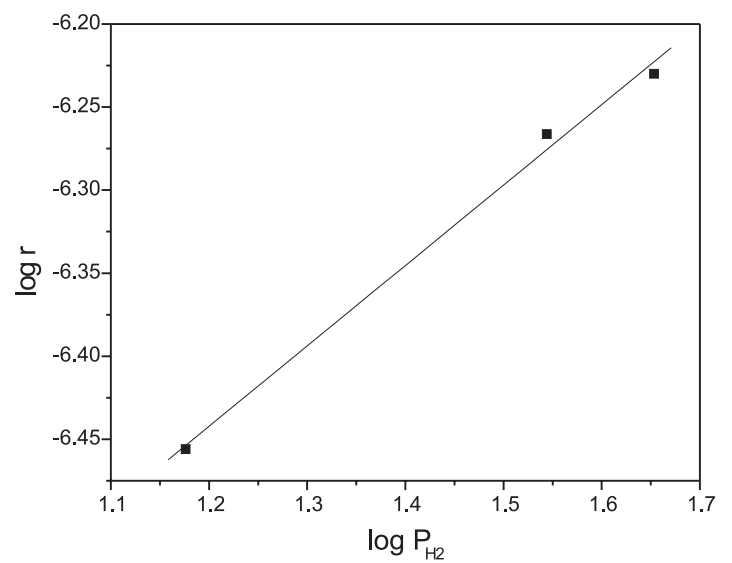

Figure 2. Hydrogenation of $\mathrm{C}_{4} \mathrm{H}_{6}$ to $\mathrm{C}_{4} \mathrm{H}_{8}$ by $\left[\mathrm{Co}(\mathrm{acac})_{2}\right.$ ] dissolved in 1: rate dependence on hydrogen pressure. Conditions are as in Table 1.

Moreover, the recovered ionic catalyst solutions possess a light violet color. These observations can explain the observed reaction order $(0.15$ on $[\mathrm{Co}])$, i.e., not all the cobalt centers are active species in the hydrogenation reaction. The 0.5 order rate dependence on hydrogen pressure is typical of hydrogen activation by homolytic addition, which is usually observed in the hydrogenation promoted by cobalt catalyst precursors. ${ }^{25}$

The activation energy calculated from these data, by plotting ln $\mathrm{k} v s$. 1/T (Figure 3), is $33.8 \mathrm{~kJ} \mathrm{~mol}^{-1}$. All these results, associated with the selectivity, strongly suggest that the mechanism of the hydrogenation reaction for the cobalt complex dissolved in the ionic liquid is the same as in general accepted for cobalt cyanide complexes dissolved in water. ${ }^{2}$

The influence of the nature of the ionic liquid on the hydrogenation of 1,3 -butadiene by $\left[\mathrm{Co}(\mathrm{acac})_{2}\right]$ is shown in Table 2.

From Table 2 it becomes evident that the catalytic activity is not significantly influenced by the nature of the non-coordinating anion of the ionic liquid whereas there is a dramatic change on selectivity. This behaviour can be related to the different solubility of 1,3-butadiene and the butenes in the ionic liquids. In the case of $\mathbf{1}$, the solubility of 1,3-butadiene, at $25^{\circ} \mathrm{C}$ and $771 \mathrm{~mm} \mathrm{Hg}$, is 4.5

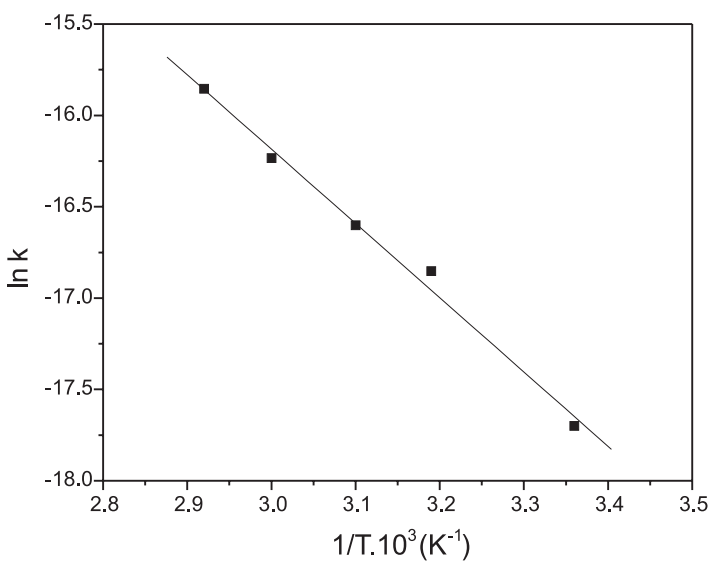

Figure 3. Hydrogenation of $\mathrm{C}_{4} \mathrm{H}_{6}$ to $\mathrm{C}_{4} \mathrm{H}_{8}$ by $\left[\mathrm{Co}(\mathrm{acac})_{2}\right]$ dissolved in 1: Arrhenius plot. Conditions are as in Table 1.

times the solubility of the butenes. However, this relative solubility decreases in the ionic liquid 3 to $2.0(1,3-$ butadiene/butenes) under the same conditions. Note that the increase in the butane formation is accompanied by the increasing solubility of the butenes intermediates in the ionic liquid. These observations strongly suggest that the 1,3-butadiene hydrogenation reaction occurs preferentially in the ionic catalyst solution. These results contrast with those obtained using $\left[\mathrm{Pd}(\mathrm{acac})_{2}\right]$ as catalyst precursor, where no changes on selectivity was observed by changing the ionic liquid. ${ }^{18}$

As shown in Table 3 other transition metal acetylacetonates complexes are also able to hydrogenate 1,3butadiene under relatively mild reaction conditions. As observed in the hydrogenation reactions with $\left[\mathrm{Co}(\mathrm{acac})_{2}\right]$, the separation of the products from the reaction mixture can be performed by simple decantation and the recovered ionic catalyst solution can be reused without any significant changes in activity or selectivity. Note that the hydrogenation of 1,3-butadiene by iron, nickel and palladium catalyst precursors under homogeneous conditions produces preferentially butane. ${ }^{26}$ Moreover, these complexes are usually activated by alkyl aluminum compounds. ${ }^{26}$

In summary, we have shown that transition metal catalyst precursors immobilized in 1-butyl-3-methyl

Table 2. Conversion (Conv.), selectivity and turnover frequency (TOF) of the hydrogenation of 1,3-butadiene at $50{ }^{\circ} \mathrm{C}, 25$ atm of $\mathrm{H}_{2}$ for $22 \mathrm{~h}$ by $\left[\mathrm{Co}(\mathrm{acac})_{2}\right](0.1 \mathrm{mmol})$ dissolved in $3 \mathrm{~mL}$ of $\mathbf{1}, \mathbf{2}$ and $\mathbf{3}$

\begin{tabular}{|c|c|c|c|c|c|c|}
\hline \multirow[t]{2}{*}{ Entry } & \multirow[t]{2}{*}{ Ionic liquid } & \multirow{2}{*}{$\begin{array}{c}\text { Conv. } \\
(\%)\end{array}$} & \multicolumn{3}{|c|}{ Selectivity (\%) } & \multirow{2}{*}{$\begin{array}{l}\text { TOF } \\
\left(\mathrm{h}^{-1}\right) \\
\end{array}$} \\
\hline & & & but-1-ene & but-2-ene & butane & \\
\hline 1 & 1 & 18 & 50 & 43 & 7 & 10.3 \\
\hline 2 & 2 & 24 & 58 & 37 & 5 & 13.7 \\
\hline 3 & 3 & 23 & 41 & 31 & 28 & 13.2 \\
\hline
\end{tabular}


Table 3. Conversion (Conv.), selectivity and turnover frequency (TOF) of the hydrogenation of 1,3-butadiene at $50{ }^{\circ} \mathrm{C}, 25$ atm of $\mathrm{H}_{2}$ of various transition metal acetil acetonate compounds $(0.1 \mathrm{mmol})$ dissolved in $3 \mathrm{~mL}$ of $\mathbf{1}$

\begin{tabular}{ccccccc}
\hline Entry & Complex & Conv. & & Selectivity $(\%)$ & & \multirow{2}{*}{ TOF } \\
\cline { 3 - 6 } & & $(\%)$ & but-1-ene & but-2-ene & butane & $\left(\mathrm{h}^{-1}\right)$ \\
\hline 1 & {$\left[\mathrm{Ni}(\mathrm{acac})_{2}\right]$} & 12 & 57 & 39 & 4 & 6.9 \\
2 & {$\left[\mathrm{Fe}(\mathrm{acac})_{3}\right]$} & 18 & 50 & 33 & 6 & 10.3 \\
3 & {$\left[\mathrm{Co}(\mathrm{acac})_{3}\right]$} & 37 & 57 & 37 & 7 & 21.2 \\
4 & {$\left[\mathrm{Co}(\mathrm{acac})_{2}\right]$} & 18 & 50 & 43 & 70.3 \\
\hline
\end{tabular}

imidazolium based ionic liquids are able to selectively hydrogenate 1,3-butadiene to butenes in a typical twophase catalytic reaction. The hydrogenated products are easily removed from the reaction mixture by simple decantation and the recovered ionic catalyst solutions can be recycled without any significant loss of catalytic efficiency. The selectivity for butenes is strongly dependent on the relative solubility of 1,3-butadiene and butenes in the ionic liquid. The selectivity for butenes can be modulated by a proper choice of the molten salt ionic strength. All these results suggest that the ionic liquid act, at least using $\left[\mathrm{Co}(\mathrm{acac})_{2}\right]$ as catalyst precursor, as a simple immobilizing solvent and the reaction occurs preferentially in the ionic catalytic phase.

\section{Acknowledgements}

This work was supported by FAPERGS and CNPq.

\section{References}

1. Parshall, G. W.; Ittel, S. D.; Homogeneous Catalysis. The Applications and Chemistry of Catalysis by Soluble Transition Metal Complexes, John Wiley \& Sons, Inc.: New York, 1992, p. 31.

2. Masters, C.; Homogeneous Transition-metal Catalysis: a Gentle Art, Chapman and Hall: London, 1981, p. 38.

3. Cornils, B.; Angew. Chem. Int. Ed. Engl. 1995, 34, 1575.

4. Hermann, W. A.; Kohlpaintner, C. W.; Angew. Chem. Int. Ed. Engl. 1993, 32, 1524.

5. Herrman, W. A.; Cornils, B.; Angew. Chem. Int. Ed. Engl. 1997, 36, 1049 .

6. Schrock, R. R.; Osborn, J.; J. Am. Chem. Soc. 1976, 98, 4450.

7. Burnett, M. G.; Connolly, P. J.; Kemball, C.; J. Chem. Soc.(A) 1968, 991.

8. Dupont, J.; de Souza, R. F.; Suarez, P. A. Z.; Chem. Rev. 2002, 102, 3667; Dupont, J.; Consorti, C.; Spencer, J.; J. Braz. Chem. Soc. 2000, 11, 337; Welton, T.; Chem. Rev. 1999, 99, 2071.
9. Chauvin, Y.; Gilbert, B.; Olivier, H.; J. Chem. Soc., Chem. Commun. 1990, 1715.

10. Chauvin, Y.; Einloft, S. M. O.; Olivier, H.; Ind. Eng. Chem. Res. 1995, 34, 1149.

11. Einloft, S. M. O.; Dietrich, F. K.; de Souza, R. F.; Dupont, J.; Polyhedron 1996, 15, 3257.

12. Chauvin, Y.; Olivier, H.; Wyrsvalski, C. N.; Simon, L. C.; de Souza, R. F.; J. Catal. 1997, 165, 275.

13. Chauvin, Y.; Mussmann, L.; Olivier, H.; Angew. Chem. Int. Ed. Engl. 1995, 34, 2698.

14. Suarez, P. A. Z.; Dullius, J. E. L.; Einloft, S. M. O.; de Souza, R. F.; Dupont, J.; Polyhedron 1996, 15, 1217.

15. Suarez, P. A. Z.; Dullius, J. E. L.; Einloft, S. M. O.; de Souza, R. F.; Dupont, J.; Inorg. Chim. Acta 1997, 255, 207.

16. Monteiro, A. L.; Zinn, F. K.; de Souza, R. F.; Dupont, J.; Tetrahedron: Asymm. 1997, 8, 177.

17. Dullius, J. E. L.; Suarez, P. A. Z.; Einloft, S. M. O.; de Souza, R. F.; Dupont, J.; Fischer, J.; De Cian, A.; Organometallics 1998, 17, 815 .

18. Dupont, J.; Suarez, P. A. Z.; Umpierre, A. P.; de Souza, R. F.; J. Braz. Chem. Soc. 2000, 11, 293

19. Ellern, J. B.; Ragsdale, R. O.; Inorg. Synth. 1978, 11, 82.

20. Bryant, B. E.; Fernelius, W. C.; Inorg. Synth. 1957, 5, 188.

21. Morris, M. L.; Moshier, R. W.; Sievers, R. E.; Inorg. Chem. 1963, 3, 411.

22. Pawlikowski, M. A.; J. Phys. Chem. 1958, 62, 440.

23. Suarez, P. A. Z.; Dullius, J. E. L.; Einloft, S. M. O.; de Souza, R. F.; Dupont, J.; J. Chim. Phys. 1998, 95, 1626.

24. Cotton, F. A.; Elder, R. C.; Inorg. Chem. 1964, 4, 1145; Cotton, F. A.; Soderberg, R. H.; Inorg. Chem. 1963, 3, 1.

25. Kwiatek, J.; Catal. Rev. 1967, 1, 37.

26. Chen, Y.; Zhu, X.; Yu, S.; Huadong Huagong Хиеуuan Xиebao 1984, 4, 463 (CA 102: 205725m); Chen, Y.; Zhu, X.; Yu, S.; Huaxue Shiji 1985, 7, 106 (CA 103: 12029z); Imaki, N.; ukumoto, Y.; Eur. Pat. Appl. EP 155,551, 1986 (CA 104: $148287 k)$.

Received: October 8, 2002 Published on the web: April 30, 2003 